\title{
ANALISIS PERBANDINGAN KONTRIBUSI DAN EFEKTIVITAS PAJAK BAHAN BAKAR KENDARAAN BERMOTOR DI PROVINSI GORONTALO DAN PROVINSI SULAWESI UTARA
}

\author{
Miswati Dalonto ${ }^{1}$, Jullie J. Sondakh², Steven J. Tangkuman ${ }^{3}$ \\ ${ }^{1,2,3}$ Fakultas Ekonomi Dan Bisnis, Jurusan Akuntansi, Universitas Sam Ratulangi, J1. Kampus Bahu, Manado, \\ 95115, Indonesia \\ E-mail : miswatidalonto95@gmail.com
}

\begin{abstract}
The contribution and the effectiveness of motorcycle fuel taxas is one of the tools that can measure how far the contribution of motorcycle fuel taxes towards original local government revenue and also how far the achievements level of tax collaction by local government in regards of motorcycle fuel taxes because of tax incomes is very crucial to build a district. This study aims to (1) Determine how big the contribution motorcycle fuel taxes toword Original government revenue in Gorontalo Province and North Sulawesi Province (2) To Determine how big the effectiveness motorcycle fuel taxes in Gorontalo Province and North Sulawesi Province (3) How the comparison of contribution and the effectiveness of motorcycle fuel taxes in Gorontalo Province and North Sulawesi Province. This study is using qualitative descriptive method. The result of this study is showing that the motorcycle fuel taxes in Gorontalo Province is stil lack of giving contribution because of the result shows that the average of percentage is 19,29\%, and on the other side, North Sulawesi Province also shows a lack of giving contribution which is $19,75 \%$ in percentage, and effectiveness motorcycle fuel taxes in Gorontalo Province and North Sulawesi Province is included as very effective criteria by showing a result of criteria level is more than $100 \%$.
\end{abstract}

Keywords: contribution; effectiveness; motorcycle fuel taxes; locally-generated revenue $(P A D)$

\section{PENDAHULUAN}

Wulandari dan Iryanie (2018:1) Otonomi daerah adalah hak wewenang dan kewajiban daerah otonom untuk mengatur dan mengurus diri sendiri urusan pemerintahan dan kepentingan masyarakat setempat sesuai dengan peraturan perundang-undangan. Dengan diberlakukannya otonomi daerah, pemerintah mampu menelusuri sumber-sumber pendapatan daerahnya, sehingga keuangan daerah dapat meningkat dan pada akhirnya dapat digunakan pada pembangunan daerah.

Pajak daerah merupakan salah satu sumber pendapatan asli daerah yang berperan penting dalam meningkatkan pendapatan daerah karena menentukan kemajuan dan pembangunan daerah. pajak daerah adalah iuran rakyat kepada daerah yang bersifat memaksa yang dipungut berdasarkan undang-undang dan tidak mendapatkan imbalan secara langsung dan digunakan sebagai kepentingan dan kebutuhan daerah. Saat ini sebagian besar pemungutan pajak di Indonesia menggunakan Self Assessment System, yaitu suatu sistem pemungutan yang wajib pajaknya boleh menghitung, membayar dan melaporkan sendiri besarnya pajak yang harus disetor. Supramono dan Damayanti $(2010: 4)$.

Undang-Undang Nomor 28 Tahun 2009 Tentang Pajak Daerah dan Retribusi Daerah, salah satu sumber penerimaan pajak daerah adalah pajak bahan bakar kendaraan bermotor, yaitu pajak atas penggunaan bahan bakar cair atau gas. Pemungutan pajak bahan bakar kendaraan bermotor dilakukan oleh produsen/importir atau nama lain sejenis atas bahan bakar yang disalurkan atau dijual kepada lembaga penyalur seperti stasiun pengisian bahan 
bakar kendaraan bermotor untuk umum (SPBU), stasiun pengisian bahan bakar untuk TNI/POLRI, agen premium dan minyak solar (APMS), premium solar packed dealer (PSPD), stasiun pengisian bahan bakar bunker (SPBB) dan penyalur bahan bakar lainnya.

Dari tahun ke tahun dapat dilihat Provinsi Gorontalo maupun Provinsi Sulawesi Utara mengalami kemajuan dalam penggunaan kendaraan bermotor, hal ini mengakibatkan semakin besarnya penggunaan bahan bakar kendaraan bermotor berdasarkan data yang diperoleh, penerimaan pajak bahan bakar kendaraan bermotor di Provinsi Gorontalo dan Provinsi Sulawesi Utara mengalami kenaikan dan juga penurunan pada tahun 2014-2018. Semakin banyaknya penggunaan bahan bakar kendaraan bermotor akan membantu meningkatkan kontribusi dan efektivitas pajak bahan bakar kendaraan bermotor terhadap pendapatan asli daerah (PAD) di Provinsi Gorontalo maupun Provinsi Sulawesi Utara.

\section{TINJAUAN PUSTAKA}

Akuntansi Pajak. Muljono (2010:2) Akuntansi pajak adalah bidang akuntansi yang berkaitan dengan perhitungan perpajakan, uang yang mengacu pada peraturan, undangundang dan aturan pelaksanaan perpajakan.

Pajak. Nurwanti (2018:1) Pajak adalah kontribusi wajib kepada negara yang terutang oleh orang pribadi atau badan yang bersifat memaksa berdasarkan undang-undang, dengan tidak mendapatkan imbalan secara langsung dan digunakan untuk keperluan negara bagi sebesar-besarnya kemakmuran rakyat.

Fungsi Pajak. Ratnawati dan Herawati (2015:2) Ada 2 fungsi pajak, yaitu

\section{1) Fungsi Budgetir}

Pemungutan pajak memberikan sumbangan terbesar pada kas negara yaitu kurang lebih 60-70\% pemungutan pajak memenuhi postur APBN. Maka dari itu, pajak merupakan salah satu penerimaan pemerintah untuk membiayai pengeluaran rutin meupun pengeluaran pembangunan.

2) Fungsi Mengatur (Regulerend)

Pemungutan pajak berfungsi sebagai alat ukur mengatur masyarakat atau untuk melaksanakan kebijakan pemerintah di bidang social dan ekonomi.

Pendapatan Asli Daerah (PAD). Menurut Anggoro (2017:18), pendapatan asli daerah merupakan pendapatan yang diperoleh pemerintah daerah atas pelaksanaan kegiatan pemerintahan dan pelayanan kepada masyarakat, serta pemanfaatan sumber daya yang dimiliki pemerintah daerah. sumber-sumber yang bisa dikembangkan daerah dalam meningkatkan pendapatan asli daerah adalah :

1. Pajak daerah, yaitu pajak-pajak yang ditentukan pemungutannya dalam peraturan daerah dan para pembayar pajak (wajib pajak) tidak menerima imbalan secara langsung dari pemerintah daerah.

2. Retribusi daerah, yaitu pungutan yang dikenakan kepada masyarakat yang menikmati secara langsung fasilitas tertentu yang disediakan pemerintah daerah, pemungutannya juga harus dituangkan dalam peraturan daerah.

3. Hasil pengelolaan kekayaan daerah yang dipisahkan, yaitu pendapatan yang diperoleh dari pengelolaan badan-badan usaha milik daerah maupun lembaga-lembaga lainnya yang dimiliki pemerintah daerah.

4. Lain-lain PAD yang sah, yaitu pendapatan yang diperoleh pemerintah daerah selain tiga jenis pendapatan tersebut diatas. Pendapatan ini antara lain adalah hasil penjualan kekayaan daerah yang tidak dipisahkan, kasa giro, pendapatan bunga, keuntungan selisih nilai tukar rupiah terhadap mata uang asing, serta komisi, potongan ataupun bentuk lain sebagai akibat dari penjualan dan/atau pengadaan barang atau jasa oleh daerah.

Pajak Daerah. Siahaan (2013:9) Pajak daerah merupakan pajak yang ditetapkan oleh pemerintah daerah dengan peraturan daerah yang wewenang pungutnya dilaksanakan oleh 
pemerintah daerah dan hasilnya digunakan untuk membiayai pengeluaran pemerintah daerah dalam pelaksanaan penyelenggaraan pemerintah dan pembangunan daerah.

Undang-undang nomor 28 tahun 2009 Tentang Pajak Daerah dan Retribusi Daerah pasal 2 ayat 1 pajak daerah Provinsi terdiri atas :

1. Pajak Kendaraan Bermotor

2. Pajak Bea Balik Nama Kendaraan Bermotor

3. Pajak Bahan Bakar Kendaraan Bermotor

4. Pajak Air Permukaan

5. Pajak Rokok

Tata Cara Pemungutan, Penyetoran dan Pelaporan Pajak Bahan Bakar

Kendaraan Bermotor. Keputusan Menteri Dalam Negeri Nomor 165 Tahun 2004 Tentang

Tata Cara Pemungutan, Penyetoran dan Pelaporan Pajak Bahan Bakar Kendaraan Bermotor.

1. Pasal 3 ayat 3 bahwa pemungutan pajak bahan bakar kendaraan bermotor dilakukan oleh penyedia bahan bakar kendaraan bermotor.

2. Pasal 12 ayat 1 , penyedia bahan bakar kendaraan bermotor wajib menyampaikan SPTPD kepada gubernur atau pejabat yang ditunjuk paling lama 5 (lima) hari kerja terhitung sejak penyetoran pajak bahan bakar kendaraan bermotor yang terutang.

3. Pasal 12 ayat 2, SPTPD sebagaimana yang dimaksud antara lain memuat data volume penjualan bahan bakar, jumlah pajak bahan bakar kendaraan bermotor yang disetor, termasuk koreksi atas data laporan bulan sebelumnya disertai dengan data pendukung lainnya.

4. Pasal 12 ayat 3, rekapitulasi laporan jumlah bahan bakar kendaraan bermotor yang terjual dan pajak bahan bakar kendaraan bermotor telah disetor kepada daerah disampaikan kepada Direktorat Jenderal Bina Administrasi Keuangan Daerah dan Badan Pengkajian Ekonomi, Keuangan dan Kerjasama Internasional Departemen Keuangan paling lambar 5 (lima) hari kerja setelah penyetoran dilakukan.

Kontribusi. Mahmudi (2010:143) dalam Hebimisa et al menyatakan Kontribusi digunakan untuk mengetahui sejauh mana pajak daerah berkontribusi dalam penerimaan pendapatan asli daerah. Firdausy (2017:92) Untuk menghitung kontribusi menggunakan rumus :

$$
\text { Kontribusi }=\frac{\text { Realisasi PBBKB }}{\text { Realisasi PAD }} \times 100 \%
$$

Tingkat kriteria kontribusi sebagai berikut :

Tabel 1. Tingkat Kriteria Kontribusi

\begin{tabular}{cc}
\hline PERSENTASE & KRITERIA \\
\hline $0.00-10 \%$ & Tidak Berkontribusi \\
$10,10 \%-20 \%$ & Kurang Berkontribusi \\
$20,10 \%-30 \%$ & Cukup Berkontribusi \\
$30,10 \%-40 \%$ & Berkontribusi \\
$40,10 \%-50 \%$ & Sangat Berkontribusi \\
\hline
\end{tabular}

Sumber : Tim Litbang Depdagri Fispol UGM (dalam Wicaksono, 2017)

Efektivitas. Mahmudi (2010:143) dalam Hebimisa et al menyatakan bahwa efektivitas merupakan hubungan keluaran dengan tujuan atau sasaran yang harus dicapai. Mahsun (2012:187) Untuk menghitung tingkat efektivitas pajak bahan bakar kendaraan bermotor menggunakan rumus, 


$$
\text { Efektivitas } \frac{\text { Realisasi PBBKB }}{\text { Target Penerimaan PBBKB }} \times 100 \%
$$

Tingkat kriteria efektivitas sebagai berikut :

Tabel 2. Tingkat Kriteria Efektivitas

\begin{tabular}{cc}
\hline PERSENTASE & KRITERIA \\
\hline$>100 \%$ & Sangat Efektif \\
$>90 \%-100 \%$ & Efektif \\
$>80 \%-90 \%$ & Efektif \\
$>60-80 \%$ & Kurang Efektif \\
$>60 \%$ & Tidak Efektif \\
\hline
\end{tabular}

Sumber : Kepmendagri, No. 690.900 .327 (dalam Wicaksono, 2017)

Penelitian Terdahulu. Ermadiani et al (2018) bahwa penerimaan pajak bahan bakar kendaraan bermotor Provinsi Sumatera Selatan dari tahun 2017 hingga 2017 termasuk dalam kategori efektif, walaupun tahun 2015, 2016 dan 2017 terjadi penurunan penerimaan pajak bahan bakar kendaraan bermotor. Rajagukguk et al (2019) Efektivitas pajak bahan bakar kendaraan bermotor di Provinsi Sulawesi Utara pada tahun 2013-2017 sangat fluktuatif dan rata-rata kontribusi pajak bahan bakar kendaraan bermotor di Provinsi Sulawesi Utara tahun 2013-2017 hanya sebesar 20,50\%.

\section{METODOLOGI PENELITIAN}

Jenis Penelitian. Jenis penelitian yang digunakan dalam penelitian ini adalah penelitian kualitatif. Tempat dan waktu penelitian Penelitian ini dilaksanakan di Badan Keuangan Daerah Provinsi Gorontalo yang beralamat di Jl. Sapta Marga, Botu, Kota Timur, Provinsi Gorontalo dan Badan Pendapatan Daerah Provinsi Sulawesi Utara yang beralamat di Jalan 17 Agustus Nomor 67, Kota Manado. Waktu penelitian akan dilakukan selama bulan April 2019 sampai dengan selesai.

Jenis, Sumber dan Metode Pengumpulan Data. Jenis data data dalam penelitian ini meliputi data kualitatif yang berupa hasil wawancara dan data kuantitatif berupa laporan penerimaan pajak bahan bakar kendaraan bermotor di Badan Keuangan Provinsi Gorontalo dan Badan Pendapatan Daerah Provinsi Sulawesi Utara. Sumber data yang digunakan dalam penelitian ini yaitu data primer dimana data yang diperoleh secara langsung di Badan Keuangan Provinsi Gorontalo dan Badan Pendapatan Daerah Provinsi Sulawesi Utara. Metode pengumpulan data adalah wawancara yang dilakukan secara langsung baik dengan pimpinan maupun pegawai yang ada di Badan Keuangan dan Badan Pendapatan Daerah untuk memperoleh data-data berupa laporan penerimaan pajak bahan bakar kendaraan bermotor pada tahun 2014-2018.

Metode Dan Proses Analisis. Metode analisis yang digunakan dalam penelitian ini yaitu menggunakan metode analisis data deskriptif kualitatif yang sifatnya membandingkan, menguraikan, menggambarkan data yang bersangkutan dengan situasi yang terjadi, dalam hal ini menganalisis data laporan keuangan atas pencapaian target dan realisasi pajak bahan bakar kendaraan bermotor (PBBKB) dan data penerimaan pendapatan asli daerah (PAD). Prosedur analisis data dalam penelitian ini antara lain :

1. Mengumpulkan data yang akan digunakan dalam penelitian ini berupa laporan keuangan penerimaan pajak bahan bakar kendaraan bermotor dan pendapatan asli daerah selama tahun 2014-2018. 
2. Menghitung dan menganalisis tingkat kontribusi dan efektivitas penerimaan pajak bahan bakar kendaraan bermotor (PBBKB) dan pendapatan asli daerah (PAD) pada tahun 2014-2018 dengan menggunakan rasio kontribusi dan efektivitas.

3. Membandingkan kontribusi dan efektivitas penerimaan pajak bahan bakar kendaraan bermotor Provinsi Gorontalo dan Provinsi Sulawesi Utara.

4. Menarik kesimpulan dari hasil penelitian dan pembahasan tentang kontribusi dan efektivitas pajak bahan bakar kendaraan bermotor Provinsi Gorontalo dan Provinsi Sulawesi Utara.

\section{HASIL PENELITIAN DAN PEMBAHASAN}

Gambaran Umum Objek Penelitian. Terbentuknya Provinsi Gorontalo berdasarkan Undang-Undang Nomor 38 Tahun 2000 tentang Pembentukan Provinsi Gorontalo, dan Dinas Pendapatan Daerah bergabung dengan Biro Keuangan dan menjadi Badan Keuangan Provinsi Gorontalo berdasarkan Peraturan Daerah Nomor 11 Tahun 2004. Badan Keuangan menjadi Dinas Keuangan Dan Aset Daerah Berdasarkan Peraturan Daerah Nomor 12 Tahun 2003 dan Peraturan Gubernur Nomor 88 Tahun 2014, kemudian pada tahun 2016 berdasarkan Peraturan Daerah Nomor 11 Tahun 2016 (Peraturan Gubernur 80 Tahun 2016) menjadi Badan Keuangan Provinsi Gorontalo sampai sekarang.

Dinas Pendapatan Daerah Provinsi Sulawesi Utara dibentuk pada tahun 1962 dengan nama Kantor Pajak, yang saat itu merupakan bagian dari pemerintahan Daerah Tingkat I Sulawesi Utara-Tengah. Pada Tahun 1964 seiring dengan terbentuknya Daerah Tingkat I Sulawesi Utara dan Perkembangan organisasi, berubah menjadi Kantor Inspeksi Pajak. Seiring dengan perkembangan organisasi, pada Tahun 1984 Kantor Inspeksi Pajak berubah menjadi Dinas dengan nama Dinas Pajak dan Pendapatan.. Pada tahun 2003 Dinas Pajak dan Pendapatan diganti menjadi Dinas Pendapatan berdasarkan Peraturan Daerah No. 23 Tahun 2003. Pada Tahun 2008 dengan ditetapkannya Peraturan Pemerintah No. 41 Tahun 2008 tentang organisasi Perangkat Daerah, maka Dinas Pendapatanmenjadi Dinas Pendapatan Daerah berdasarkan Peraturan Daerah Provinsi Sulawesi Utara No. 3 Tahun 2008 tentang Organisasi dan Tata Kerja Dinas Daerah Provinsi Sulawesi Utara. Pada tahun 2007 Dinas Pendapatan Daerah berubah menjadi Badan Pengelolah Pajak dan Retribusi Daerah, Kepala Badan dipercayakan Kepada Olvie Atteng, SE, M.Si, tepatnya pada tanggal 3 Januari 2016, dan pada Januari tahun 2019 Badan Pengelolah Pajak Dan Retribusi Daerah berubah menjadi Badan Pendapatan Daerah Provinsi Sulawesi Utara sampai dengan sekarang.

\subsection{Hasil Penelitian}

Target Dan Realisasi Penerimaan Pajak Bahan Bakar Kendaraan Bermotor dan Pendapatan Asli Daerah Provinsi Gorontalo. Berdasarkan hasil penelitian yang dilakukan di Badan Keuangan Provinsi Gorontalo, maka diperoleh hasil berupa data target dan realisasi penerimaan pajak bahan bakar kendaraan bermotor Provinsi Gorontalo pada tahun 20142018. Untuk lebih jelasnya dapat dilihat pada tabel dibawah ini.

Tabel 3. Target Dan Realisasi PBBKB Provinsi Gorontalo Tahun 2014-2018

\begin{tabular}{ccc}
\hline Tahun & Target PBBKB $(\mathbf{R p})$ & Realisasi PBBKB $(\mathbf{R p})$ \\
\hline 2014 & $50.425 .707 .424,80$ & $52.864 .709 .648,00$ \\
2015 & $59.316 .396 .987,14$ & $58.957 .206 .576,00$ \\
2016 & $61.547 .810 .480,00$ & $57.945 .706 .573,23$ \\
2017 & $60.547 .810 .480,00$ & $67.786 .751 .229,00$ \\
2018 & $68.236 .759 .693,00$ & $73.291 .760 .360,00$ \\
\hline
\end{tabular}

Sumber : Badan Keuangan Provinsi Gorontalo (2019) 
Target Dan Realisasi Pendapatan Asli Daerah Provinsi Gorontalo. Dibawah ini diuraikan data target dan realisasi pendapatan asli daerah Provinsi Gorontalo pada tahun 2014-2018.

Tabel 4. Target Dan Realisasi PAD Provinsi Gorontalo Tahun 2014-2018

\begin{tabular}{ccc}
\hline Tahun & Target PAD (Rp) & Realisasi PAD (Rp) \\
\hline 2014 & $291.096 .154 .035,41$ & $281.920 .210 .038,54$ \\
2015 & $319.972 .267 .527,24$ & $289.557 .151 .141,95$ \\
2016 & $357.884 .605 .814,69$ & $311.223 .202 .411,81$ \\
2017 & $361.547 .915 .035,93$ & $348.267 .663 .013,38$ \\
2018 & $370.394 .296 .330,57$ & $381.512 .157 .604,00$ \\
\hline
\end{tabular}

Sumber : Badan Keuangan Provinsi Gorontalo (2019)

Target dan Realisasi Penerimaan Pajak Bahan Bakar Kendaraan Bermotor Provinsi Sulawesi Utara tahun 2014-2018. Target dan realisasi pajak bahan bakar kendaraan bermotor dan pendapatan asli daerah pada tahun 2014-2018 yang diperoleh secara langsung di Badan Pendapatan Asli Daerah Provinsi Sulawesi Utara diuraikan pada tabel dibawah ini .

Tabel 5. Target Dan Realisasi PBBKB Provinsi Sulawesi Utara Tahun 2014-2018

\begin{tabular}{ccc}
\hline Tahun & Target PBBKB $(\mathbf{R p})$ & Realisasi PBBKB $(\mathbf{R p})$ \\
\hline 2014 & 183.336 .168 .000 & 196.938 .425 .823 \\
2015 & 220.123 .486 .640 & 203.967 .373 .500 \\
2016 & 181.123 .486 .640 & 187.366 .177 .880 \\
2017 & 205.316 .400 .000 & 217.589 .107 .612 \\
2018 & 223.689 .783 .716 & 249.032 .913 .395 \\
\hline
\end{tabular}

Sumber : Badan Pendapatan Daerah Provinsi Sulawesi Utara (2019)

Target dan Realisasi Pendapatan Asli Daerah Provinsi Sulawesi Utara Tahun 20142018. Target dan realisasi pendapatan asli daerah pada tahun 2014-2018 diuraikan pada tabel berikut ini.

Tabel 6. Target Dan Realisasi PAD Provinsi Sulawesi Utara Tahun 2014-2018

\begin{tabular}{crr}
\hline Tahun & Target PAD $($ Rp) & Realisasi PAD (Rp) \\
\hline 2014 & 1.002 .152 .580 .230 & 941.279 .364 .862 \\
2015 & 1.089 .288 .358 .000 & 1.012 .945 .961 .386 \\
2016 & 979.353 .945 .492 & 981.044 .550 .486 \\
2017 & 1.094 .319 .346 .536 & 1.146 .674 .827 .814 \\
2018 & 1.213 .016 .074 .474 & 1.265 .412 .698 .030 \\
\hline
\end{tabular}

Sumber : Badan Pendapatan Daerah Provinsi Sulawesi Utara (2019)

\subsection{Pembahasan}

Kontribusi Pajak Bahan Bakar Kendaraan Bermotor Provinsi Gorontalo tahun 2014-2018. Berikut dibawah ini merupakan tabel kontribusi pajak bahan bakar kendaraan bermotor Provinsi Gorontalo pada tahun 2014-2018. 


\begin{tabular}{ccccc}
\hline \multicolumn{5}{c}{ Tabel 7. Kontribusi PBBKB Terhadap PAD Provinsi Gorontalo Tahun 2014-2018 } \\
\hline \multirow{2}{*}{ Tahun } & Realisasi PBBKB $(\mathbf{R p})$ & Realisasi PAD $(\mathbf{R p})$ & $\begin{array}{c}\text { Persentase } \\
(\boldsymbol{\%})\end{array}$ & Kriteria \\
\hline 2014 & $52.864 .709 .648,00$ & $281.920 .210 .038,54$ & 18,75 & Kurang Berkontribusi \\
2015 & $58.957 .206 .576,00$ & $289.557 .151 .141,95$ & 20,36 & Cukup Berkontribusi \\
2016 & $57.945 .706 .573,23$ & 311.223 .202 .411 .81 & 18,61 & Kurang Berkontribusi \\
2017 & $67.786 .751 .229,00$ & $348.267 .663 .013,38$ & 19,46 & Kurang Berkontribusi \\
2018 & $73.291 .760 .360,00$ & $381.512 .157 .604,00$ & 19,21 & Kurang Berkontribusi \\
& & Rata-Rata Persentase & 19,27 & Kurang Berkontribusi \\
\hline
\end{tabular}

Sumber : Data Olahan (2019)

Berdasarkan tabel 7 diatas dapat dilihat bahwa pajak bahan bakar kendaraan bermotor Provinsi Gorontalo pada tahun 2014 hingga 2018 masih kurang berkontribusi terhadap pendapatan asli daerah Provinsi Gorontalo. Pada tahun 2014 pajak bahan bakar kendaraan bermotor memberikan kontribusi sebesar $18,75 \%$ pada pendapatan asli daerah dengan tingkat kriteria kurang berkontribusi, tahun 2015 naik sebesar 1,61\% dari tahun sebelumnya menjadi $20,36 \%$ dengan tingkat kriteria cukup berkontribusi terhadap pendapatan asli daerah, dan dalam 3 tahun terakhir masuk dalam tingkat kriteria kurang berkontribusi yakni tahun 2016 turun kembali sebesar 1,75\% dari tahun sebelumnya menjadi 18,61\%, tahun 2017 kontribusi pajak bahan bakar kendaraan bermotor mengalami peningkatan sebesar $0,85 \%$ dari tahun sebelumnya dan memberikan kontribusi sebesar 19,46\% terhadap pendapatan asli daerah dan tahun 2018 pajak bahan bakar kendaraan bermotor mengalami penurunan sebesar $0,25 \%$ dan berkontribusi sebesar 19,21\% pada pendapatan asli daerah. Berdasarkan hasil penerimaan pajak bahan bakar kendaraan bermotor hanya mampu memberikan kontribusi sebesar 19,27\% terhadap pendapatan asli daerah pada tahun 2014-2018 dan masuk dalam kriteria kurang berkontribusi.

Kontribusi Pajak Bahan Bakar Kendaraan Bermotor Provinsi Sulawesi Utara tahun 2014-2018. Berikut dibawah ini merupakan tabel kontribusi pajak bahan bakar kendaraan bermotor Provinsi Sulawesi Utara pada tahun 2014-2018.

Tabel 8. Kontribusi PBBKB Terhadap PAD Provinsi Sulawesi Utara Tahun 2014-2018

\begin{tabular}{ccccc}
\hline Tahun & Realisasi PBBKB $(\mathbf{R p )}$ & $\begin{array}{c}\text { Realisasi PAD } \\
(\mathbf{R p})\end{array}$ & $\begin{array}{c}\text { Persentase } \\
(\boldsymbol{\%})\end{array}$ & Kriteria \\
\hline 2014 & 196.938 .425 .823 & 941.279 .364 .862 & 20,92 & Cukup Berkontribusi \\
2015 & 203.967 .373 .500 & 1.012 .945 .961 .386 & 20,13 & Cukup Berkontribusi \\
2016 & 187.366 .177 .889 & 981.044 .550 .486 & 19,09 & Kurang Berkontribusi \\
2017 & 217.589 .107 .612 & 1.146 .674 .827 .814 & 18,97 & Kurang Berkontribusi \\
2018 & 249.032 .913 .395 & 1.265 .412 .698 .030 & 19,67 & Kurang Berkontribusi \\
& & Rata-Rata Persentase & 19,75 & Kurang Berkontribusi \\
\hline
\end{tabular}

Sumber : Data Olahan (2019)

Dapat dilihat pada tabel 8 perhitungan kontribusi pajak bahan bakar kendaraan bermotor Provinsi Sulawesi Utara tahun 2014 sampai 2018 masih berada dalam kriteria kurang berkontribusi terhadap pendapatan asli daerah. Pada tahun 2015 merupakan kontribusi terbesar pajak bahan bakar kendaraan bermotor terhadap pendapatan asli daerah dengan memberikan kontribusi sebesar 20,92\% masuk dalam tingkat kriteria cukup berkontribusi, pada tahun 2016 mengalami penurunan sebesar 0,79\% dari tahun sebelumnya dengan memberikan kontribusi sebesar 20,13\% terhadap pendapatan asli daerah, namun pada 3 tahun terakhir masuk dalam tingkat kriteria kurang berkontribusi yakni pada tahun 2016 mengalami penurunan lagi dari tahun sebelumnya sebesar 1,04\% dan memberikan kontribusi sebesar 19,09, dan pada tahun 2014 ini penurunan kontribusi paling rendah dari tahun-tahun sebelumnya dengan memberikan kontribusi sebesar 18,97\% terhadap pendapatan asli daerah 
dan pada tahun 2018 terjadi peningkatan dari tahun sebelumnya sebesar $0,7 \%$ dan memberikan kontribusi sebesar 19,67\%.

Efektivitas Pajak Bahan Bakar Kendaraan Bermotor Provinsi Gorontalo tahun 2014-2018. Berikut tabel efektivitas pajak bahan bakar kendaraan bermotor Provinsi Gorontalo pada tahun 2014-2018.

Tabel 9. Efektivitas Penerimaan PBBKB Provinsi Gorontalo Tahun 2014-2018

\begin{tabular}{ccccc}
\hline Tahun & $\begin{array}{c}\text { Target PBBKB } \\
(\mathbf{R p})\end{array}$ & $\begin{array}{c}\text { Realisasi PBBKB } \\
(\mathbf{R p})\end{array}$ & $\begin{array}{c}\text { Persentase } \\
(\mathbf{\%})\end{array}$ & Kriteria \\
\hline 2014 & $50.425 .707 .424,80$ & $52.864 .709 .648,00$ & 104,84 & Sangat Efektif \\
2015 & $59.316 .396 .987,14$ & $58.957 .206 .576,00$ & 99,39 & Efektif \\
2016 & $61.547 .810 .480,00$ & $57.945 .706 .573,23$ & 94,15 & Efektif \\
2017 & $60.547 .810 .480,00$ & $67.786 .751 .229,00$ & 111,96 & Sangat Efektif \\
2018 & $68.236 .759 .693,00$ & $73.291 .760 .360,00$ & 107,41 & Sangat Efektif \\
& & Rata-Rata Persentase & 103,55 & Sangat Efektif \\
\hline
\end{tabular}

Sumber : Data Olahan (2019)

Dari tabel 9 diatas maka dapat dilihat bahwa tingkat efektivitas pajak bahan bakar kendaraan bermotor Provinsi Gorontalo dengan rata-rata persentase 103,55\%, dan masuk dalam kriteria sangat efektif. Persentase paling tinggi yaitu pada tahun 2017 sebesar 111,96\% dengan tingkat kriteria sangat efektif, dan selanjutnya pemungutan pajak dengan persentase 107,41\% ada pada tahun 2018 dengan tingkat kriteria sangat efektif, dan pada tahun 2014 tingkat persentase efektivitas sebesar 104,84\%, pada tahun 2015 tingkat kriteria efektif karena persentase efektivitas sebesar 99,93\% dan tahun 2016 merupakan tingkat persentase paling rendah yaitu sebesar 94,15\% namun masih dalam tingkat kriteria efektif,

Efektivitas Pajak Bahan Bakar Kendaraan Bermotor Provinsi Sulawesi Utara tahun 2014-2018. Berikut dibawah ini merupakan tabel efektivitas pajak bahan bakar kendaraan bermotor Provinsi Sulawesi Utara tahun 2014-2018.

Tabel 10. Efektivitas Penerimaan PBBKB Provinsi Sulawesi Utara Tahun 2014-2018

\begin{tabular}{ccccc}
\hline Tahun & $\begin{array}{c}\text { Target PBBKB } \\
(\mathbf{R p})\end{array}$ & $\begin{array}{c}\text { Realisasi PBBKB } \\
(\mathbf{R p})\end{array}$ & $\begin{array}{c}\text { Persentase } \\
(\mathbf{\%})\end{array}$ & Kriteria \\
\hline 2014 & 183.336 .168 .000 & 196.938 .425 .823 & 107,42 & Sangat Efektif \\
2015 & 220.123 .486 .640 & 203.967 .373 .500 & 92,66 & Efektif \\
2016 & 181.123 .486 .640 & 187.366 .177 .880 & 103,45 & Sangat Efektif \\
2017 & 205.316 .400 .000 & 217.589 .107 .612 & 105,98 & Sangat Efektif \\
2018 & 223.689 .783 .716 & 249.032 .913 .395 & 111,33 & Sangat Efektif \\
& & Rata-Rata Persentase & 104,16 & Sangat Efektif \\
\hline
\end{tabular}

Sumber : Data Olahan (2019)

Berdasarkan tabel 10 dapat dilihat rata-rata efektivitas pajak bahan bakar kendaraan bermotor Provinsi Sulawesi Utara pada tahun 2014-2018 sangat efektif dengan rata-rata persentase berada diatas $100 \%$. Persentase efektivitas paling tinggi dalam penerimaan pajak bahan bakar kendaraan bermotor ada pada tahun 2018 yaitu sebesar 111,33\% dengan kriteria sangat efektif, dan selanjutnya persentase efektivitas 107,42\% pada tahun 2014, tahun 2017 persentase efektivitas pajak bahan bakar kendaraan bermotor sebesar 105,98\% dan tahun 2016 persentase sebesar 103,45\% dan masuk dalam tingkat kriteria sangat efektif, namun pada tahun 2015 masuk dalam tingkat kriteria efektif dengan persentase sebesar 92,66\%. 
Perbandingan Kontribusi Pajak Bahan Bakar Kendaraan Bermotor Provinsi Gorontalo dan Provinsi Sulawesi Utara tahun 2014-2018. Berikut dibawah ini merupakan tabel perbandingan kontribusi pajak bahan bakar kendaraan bermotor Provinsi Gorontalo dan Provinsi Sulawesi Utara pada tahun 2014-2018.

Tabel 11. Perbandingan Kontribusi PBBKB Provinsi Gorontalo dan Provinsi Sulawesi Utara Tahun 2014-2018

\begin{tabular}{cccc}
\hline Provinsi & Tahun & Kontribusi $(\boldsymbol{\%})$ & $\begin{array}{c}\text { Rata-Rata } \\
\text { Persentase } \\
(\boldsymbol{\%})\end{array}$ \\
\hline \multirow{3}{*}{ Gorontalo } & 2014 & 18.75 & \\
& 2015 & 20.36 & 19,27 \\
& 2016 & 18.61 & \\
\hline \multirow{3}{*}{ Sulawesi Utara } & 2017 & 19.46 & 19,75 \\
& 2018 & 19.21 & \\
& 2014 & 20.92 & \\
& 2015 & 20.13 & \\
\hline
\end{tabular}

Sumber : Data Olahan (2019)

Berdasarkan data diatas dari tabel 11 dapat dilihat perbandingan kontribusi pajak bahan bakar kendaraan bermotor antara Provinsi Gorontalo dan Provinsi Sulawesi Utara tidak terlalu signifikan, rata-rata persentase untuk Provinsi Gorontalo sebesar 19,27\% dan Provinsi Sulawesi Utara sebesar 19,75\%. Untuk rata-rata persentase kedua Provinsi ini masuk dalam kriteria kurang berkontribusi namun Provinsi Sulawesi utara masih dapat memberikan kontribusi lebih besar dari provinsi gorontalo dengan selisih persentase sebesar 0,48\% .

Perbandingan Efektivitas Pajak Bahan Bakar Kendaraan Bermotor Provinsi Gorontalo dan Provinsi Sulawesi Utara Tahun 2014-2018. Berikut tabel perbandingan efektivitas pajak bahan bakar kendaraan bermotor pada tahun 2014-2018.

Tabel 12. Perbandingan Efektivitas PBBKB Provinsi Gorontalo dan Provinsi Sulawesi Utara Tahun 2014-2018

\begin{tabular}{cccc}
\hline Provinsi & Tahun & Efektivitas $(\boldsymbol{\%})$ & $\begin{array}{c}\text { Rata-Rata } \\
\text { Persentase } \\
(\boldsymbol{\%})\end{array}$ \\
\hline \multirow{3}{*}{ Gorontalo } & 2014 & 104.84 & \\
& 2015 & 99.39 & 103,55 \\
& 2016 & 94.15 & \\
\hline \multirow{2}{*}{ Sulawesi Utara } & 2017 & 111.96 & \\
& 2018 & 107.41 & 104,16 \\
& 2014 & 107.42 & \\
\hline
\end{tabular}

Sumber : Data Olahan (2019)

Pada tabel 12 dilihat dengan jelas bahwa rata-rata efektivitas pajak bahan bakar kendaraan bermotor pada tahun 2014-2018 Provinsi Gorontalo sebesar 103,55\% dan Provinsi Sulawesi Utara sebesar 104,16\% dengan tingkat kriteria sangat efektif. Namun Provinsi 
Sulawesi Utara masih lebih tinggi tingkat efektivitas pajak bahan bakar kendaraan bermotor dibandingkan dengan Provinsi Gorontalo dengan selisih persentase sebesar 0,61\%.

\section{KESIMPULAN DAN SARAN}

\subsection{Kesimpulan}

Berdasarkan hasil penelitian dan pembahasan pada penelitian ini, dapat ditarik kesimpulan bahwa :

1. Kontribusi pajak bahan bakar kendaraan bermotor terhadap pendapatan asli daerah Provinsi Gorontalo pada tahun 2014 sampai dengan 2018 berkisar pada 18,61\% hingga $20,36 \%$ dengan rata-rata kontribusi pajak bahan bakar kendaraan bermotor sebesar 19,27\% yang berarti kurang berkontribusi terhadap pendapatan asli daerah dan kontribusi pajak bahan bakar kendaraan bermotor tehadap pendapatan asli daerah Provinsi Sulawesi Utara pada tahun 2014 sampai dengan 2018 berkisar pada 18,97 sampai 20,92\% dengan rata-rata kontribusi sebesar $19,75 \%$ dan masih dalam tingkat kriteria kurang berkontribusi terhadap pendapatan asli daerah.

2. Efektivitas pajak bahan bakar kendaraan bermotor Provinsi Gorontalo pada tahun 2014 sampai dengan 2018 berkisar antara 94,15\% hingga 111,96\%, dengan rata-rata efektivitas pajak bahan bakar kendaraan bermotor adalah sebesar 103,55\% yang berarti masuk dalam kriteria sangat efektif dan efektivitas pajak bahan bakar kendaraan bermotor Provinsi Sulawesi Utara pada tahun 2014 sampai dengan 2018 berkisar pada $92,66 \%$ hingga $111,33 \%$ dengan rata-rata persentase $104,16 \%$ dengan kriteria sangat efektif.

3. Perbandingan kontribusi pajak bahan bakar kendaraan bermotor terhadap pendapatan asli daerah antara Provinsi Gorontalo dan Sulawesi Utara berdasarkan hasil perhitungan kontribusi pajak bahan bakar kendaraan bermotor menunjukan hasil yang hampir sama dimana Provinsi Sulawesi Utara dapat memberikan kontribusi lebih besar dari pada Provinsi Gorontalo, namun perbedaan rata-rata tingkat kontribusi hanya memiliki selisih sebesar 0,48\% antara Provinsi Sulawesi Utara dan Provinsi Gorontalo dan perbandingan efektivitas pajak bahan bakar kendaraan bermotor antara Provinsi Gorontalo dan Provinsi Sulawesi Utara berdasarkan tingkat efektivitas antara kedua Provinsi masuk dalam kriteria sangat efektif, namun Provinsi Sulawesi Utara menunjukan lebih tinggi persentase efektif dari Provinsi Gorontalo dengan selisih sebesar 0,61\%.

\subsection{Saran}

Berdasarkan kesimpulan yang telah diperoleh dari hasil penelitian, maka saran yang dapat diberikan yaitu antara lain :

1. Bagi Badan Keuangan Provinsi Gorontalo Dan Badan Pendapatan Daerah Provinsi Sulawesi Utara, melakukan sebuah upaya seperti sosialisasi baik langsung maupun melalui media tentang pentingnya pajak dalam pembangunan daerah. Serta mempertahankan dan meningkatkan pengawasan dan pemeriksaan atas kebenaran jumlah pendistribusian penggunaan bahan bakar pada DEPO, stasiun pengisian bahan bakar untuk umum (SPBU), stasiun pengisian bahan bakar untuk TNI/POLRI, agen premium dan minyak solar (APMS) dan penyalur bahan bakar lainnya yang akan menjual BBM pada semua sektor usaha kegiatan ekonomi.

2. Bagi penyedia bahan bakar kendaraan bermotor, lebih memperhatikan untuk pembayaran dan melaporkan pajak bahan bakar kendaraan bermotor karena pajak sangat penting untuk pembangunan disuatu daerah karena sebagian besar penerimaan daerah itu berasal dari pajak selain bantuan langsung dari pusat. 


\section{DAFTAR PUSTAKA}

Anggoro, D. D. (2017). Pajak Daerah dan Retribusi Daerah. Cetakan pertama. Malang: Penerbit UB Press.

Ermadiani., DP, R. T., \& Rini, D. (2018). Analisis Atas Penerimaan Pajak Bahan Bakar Kendaraan Bermotor Dalam menunjang peningkatan pajak asli daerah. Jurnal Ilmiah $\begin{array}{llll}\text { Ekonomi Global Masa } & \text { Kini, } & \text { 125-134. }\end{array}$ http://ejournal.uigm.ac.id/index.php/EGMK/article/download/557/738

Firdausy, C. M. (2017). Optimalisasi Kebijakan Pemerintah Daerah. Jakarta: Yayasan Pustaka Bogor Indonesia.

Hebimisa, M. T., Sondakh, J. J., \& Wangkar, A. (2017). Analisis Efektivitas Dan Kontribusi Penerimaan Pajak Reklame, Pajak Bumi Bangunan Terhadap Pendapatan Asli Daerah Kabupaten Siau Tagulandang Biaro. Going Concern: Jurnal Riset Akuntansi, 12(2), 1021-1032. https://doi.org/10.32400/gc.12.2.18529.2017

Keputusan Menteri Dalam Negeri Nomor 165 Tahun 2004 Tentang Tata Cara Pemungutan, Penyetoran Dan Pelaporan Pajak Bahan Bakar Kendaraan Bermotor.

Mahsun, M. (2012). Pengukuran Kinerja Sektor Publik. Edisi Pertama. Yogyakarta: Penerbit BPFE.

Muljono, D. (2010). Panduan Brevet Pajak-Akuntansi Pajak dan Ketentuan Umum Perpajakan. Edisi I. Yogyakarta: Penerbit Andi.

Nurwanti, S. (2018). Perpajakan. Yogyakarta: Istana Media.

Rajagukguk, T. M., Tinangon, J. J., \& Wokas, H. R. N. (2019). Analisis Efektivitas Sistem Pengendalian Internal Pajak Bahan Bakar Kendaraan Bermotor Dan Kontribusinya Terhadap Pendapatan Asli Daerah Provinsi Sulawesi Utara. Going Concern: Jurnal Riset Akuntansi, 14(1), 73-79. https://doi.org/10.32400/gc.14.1.22289.2019

Ratnawati, J., \& Hernawati, R. I. (2015). Dasar-Dasar Perpajakan. Edisi I. Yogyakarta: Deepublish.

Siahaan, M. P. (2013). Pajak Daerah Dan Retribusi Daerah. Jakarta: PT. Raja Grafindo Persada.

Supramono., \& Damayanti, T. W. (2010). Perpajakan Indonesia, Mekanisme dan Perhitungan. Edisi I. Yogyakarta: Penerbit Andi.

Undang-Undang Nomor 28 Tahun 2009 Tentang Pajak Daerah dan Retribusi Daerah.

Wicaksono, G. (2017). Analisis Efektivitas Dan Kontribusi Pajak Bumi Bangunan Perdesaan Dan Perkotaan (PBB P2) Terhadap Pendapatan Asli Daerah (PAD) Kabupaten $\begin{array}{llll}\text { Jember. Jurnal STIE } & \text { SEMARANG, } & 9(1), & 81-89 .\end{array}$ http://media.neliti.com/media/publication/131406

Wulandari, P. A., \& Iryanie, E. (2018). Pajak Daerah Dalam Pendapatan Asli Daerah. Cetakan Pertama. Yogyakarta: Deepublish. 